\title{
EXCURSION TO THE DENEHOLES OF HANGMAN'S WOOD, NEAR GRAYS THURROCK, ESSEX.
}

\author{
(In connection with the Essex Field Club.) \\ IITH AND I2TH AUgUST, I893.
}

Directors:-T. V. Holmes, F.G.S., and W. Cole, Hon. Sec., E.F.C.

(Report by T. V. Holmes.)

The Association visited these pits on May 9th, 1885, and a Report of the excursion is given, Proc. Geol. Assoc., vol. ix, p. I 79 (Nov. 1885). On that occasion, owing to the labours of the Denehole Exploration Committee of the Essex Field Club in the previous autumn, the party was enabled to enter I 2 distinct deneholes on descending a single shaft. The Exploration Committee continued its work in the autumn of 1887 , and gained admission into two more pits, which were unfortunately too much choked with débris to be of any use. Sifting operations were also continued. The exploration was brought to a close in October, $\mathbf{1 8 8 7}$, after six weeks' subterranean work, and a Report by Messrs. T. V. Holmes and W. Cole, to whom the Committee had entrusted the direction of the work, was published by the Essex Field Club in December, I887. It is fully illustrated by maps, plans, and sections, and contains, in addition, Notes by Messrs. E. T. Newton, F. W. Rudler, F. J. Bennett, H. B. Woodward, and F. C. J. Spurrell.*

Referring those who wish for full particulars to that Report, a brief summary of the conclusions of its writers may be useful here. Trenches dug in the surface of the Wood showed the great care which had been taken by the denehole makers to preserve the original flattened contour of the ground. The surface-gravel had been carefully spread about and the underlying Thanet Sand diffused evenly over the gravel, while not a single fragment of Chalk could anywhere be seen. This evidently implied a desire to keep the position of the deneholes as much of a secret as possible. Then the separation of each pit, and their concentration in a spot where the Chalk is nearly 60 feet beneath the surface, though there is plenty of bare Chalk within a mile, showed that the object was not to obtain Chalk. The more probable hypothesis that they were flint-mines was also found to have no evidence in its favour. For the exploration showed that

* It may be obtained from Mr. W. Cole, 7, Knighton Villas, Buchhurst Hill, Essex (Price $2^{i} \cdot$ ).

OCTOPER, 1893 . 
the only conspicuous flint band in the pits had never been worked; and no flint cores, flakes, or implements were found, though many large flints had been used to line the upper part of the shaft, and were conspicuous in the lower portion of the heap existing at the base of each shaft when the exploration was begun.

On the other hand, owing to the immense amount of débris in each pit, and to the narrowness of the shafts, which prevented the removal of rubbish to the surface in consequence of the great amount of time and expense it would have necessitated, it was possible to reach the floor only in small areas here and there. And as any clue to the antiquity of the pits could be furnished only by objects found on or close to the floor, the bones, pottery, etc., found there were insufficient to establish the approximate age of these deneholes with any approach to certainty. The absence of worked flints seemed to imply a later date than the Neolithic Period, while allusions to them as "King Cunobeline's gold mines," in the time of King Henry IV., show that they were looked upon as works of unknown antiquity and function at the beginning of the 15 th century. As to the uses for which they were constructed it seemed most likely that they had been intended to serve chiefly as granaries. Those interested in the subject of subterranean granaries may be referred to Mr. Spurrell's paper on Deneholes in The Archaological Journal for I882, or to that by the same writer appended to the Denehole Exploration Report already mentioned; also to a paper by the present writer "On Some Curious Excavations in the Isle of Portland," Proc. Geol. Assoc., vol. viii, No. 7, p. 404 (July, I 884). In addition may be mentioned a "Note on the use of Pits in Brittany for the Storage of Grain." by Mr. Charles Browne, in The Essex Naturalist for January and February, I 888. It is gratifying to be able to state that Prof. T. G. Bonney, in acknowledging the receipt of a copy of the Denehole Report, remarked that he thought our conclusion that the Hangman's Wood pits had been originally used mainly as granaries a very probable one; adding that subterranean granaries resembling them existed in Syria.

It was a matter of considerable interest to the Directors to note the changes that had taken place since the conclusion of the exploration in 1887 . For their tunnels had allowed currents of air to pass through many pits previously closed and stagnant. No appreciable change for the worse, however, seemed to have been caused by the ventilating currents, though much harm had resulted from the mischievous stupidity of unauthorised persons who had visited the pits. The visitor to Hangman's Wood from Grays, who walks along the wood skirting the southern boundary of the wood, will pass on the right (or southern) side of the road three of the five open-shafted deneholes. Near them, but north of the road, is another open-shafted pit, the fifth being about 40 
yards still further north. The pit near, but north of, the road (called No. 3 in the Report) is that by which hitherto almost all descents have been made. It was our headquarters during the Exploration, and from it we tunnelled in three different directions. We naturally, therefore, had our apparatus for descent fixed over it on this occasion. The lower part of the shaft, however, was found to be full of the trunks of young oak and ash trees, and many more were found in the chambers below, when we at last managed to enter them. In this pit, as in others, the cylindrical shaft through the Thanet Sand had been continued for three or four feet in the Chalk, and then the lateral excavations had been begun. The two primary chambers, as usual, were in the same straight line but on different sides of the shaft, two lateral chambers on each side having been afterwards added, so that the ground-plan of the denehole had acquired the ordinary double-trefoil shape. And the continuation of the shaft from the roof of the chambers to the floor consisted of two masses of chalk, one on each side, six or seven feet broad, and with a space of four to five feet, or thereabouts, between them. In 1887 a visitor standing at the base of the shaft with one of the primary chambers in front of him would have had a massive chalk pillar on his right and another on his left. But in August, 1893, he would have found that one of these massive pillars had been wholly knocked away and that the two lateral chambers nearest to the tunnel leading to the open-shafted pits south of the road (Nos. 2 and 4 ) had been knocked into one. The massive pillar of Chalk between the shaft $(s)$ and a small hole in the partition $(x)$ between these two chambers had been wantonly destroyed. The diagram below, taken from the ground plan given in the Report, will show the amount of damage done to the stability of the pit better than any verbal description. The denehole constructors frequently (as shown in Fig. 3 of the Report) enlarged the available area in a pit by removing most of the partition separating the lateral chambers, but they were careful to leave a massive pillar of chalk close to the shaft on each side in the position of that so mischievously removed. Probably the hurling down of the tree trunks did an amount of damage to the chalk at the base of the shaft which suggested to some stupid intruders that complete destruction might be effected by the use of the trees as battering rams.

Turning to the other side of No. 3, we saw that there was a hole, about three feet by two feet, in the thin partition separating the adjacent chambers of Nos. 3 and 9 . This did not exist in r 887, but as the concussions attending the destruction of the Chalk pillar 30 or 40 feet away must have been very considerable, they were, in all probability, the cause of its appearance. It certainly is not a work of design. It is probable that most, if not all, of the holes in the thin partitions between contiguous 
Diagram to Show the Damage Done in No. 3. (Front Pian in Denehole Exploration Report).

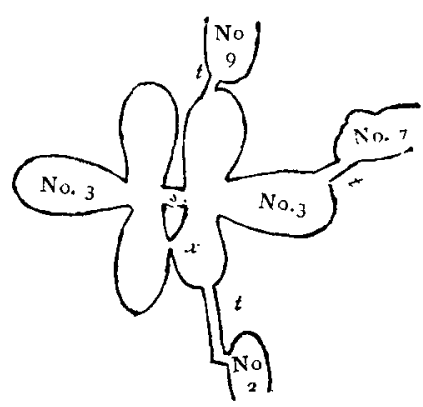

No. 3. Denehole descended IIth and I2th August, 1893 (ground plan). Nos. 2, 7, 9. Adjacent deneholes.
t. Tunnels from No. 3 .
s. Shaft.
$x$. Hole in partition between lateral chambers.

Scale:-one inch $=40$ feet. 
chambers of different deneholes may have been produced in a similar way by concussions arising from the sudden fall of masses of material centuries after the disuse of the pits.

The excavations made during our Exploration in the heaps at the base of the shafts remained unchanged. We at first thought it prudent to tunnel through the Chalk in every case, rather than to trust to a passage made through the Thanet Sand which forms the greater part of these mounds. As the work progressed we ventured on occasional holes through the mounds (where they consisted of compacted Thanet Sand) with satisfactory results.

At the base of the shaft of one of the open-shafted pits south of the road, the five-chambered denehole shown in the circular of the Essex Field Club (No. 2), Mr. Cole found a poor dog in a state of extreme emaciation, but otherwise unhurt. Though it thankfully accepted the meat out of several sandwiches it refused water, an eccentricity, perhaps, to be accounted for by the dampness of the air in the deneholes, and their comparatively low temperature at this time of year. It was stated on Saturday afternoon that the difference between the surface and subterranean temperatures at Hangman's Wood was 23 degrees, a circumstance which caused the eighty persons descending into the pits to feel that the denehole excursion was particularly well timed. The dog was brought to the surface, and when last heard of had continued to make rapid progress towards complete restoration to health.

Captain Whitmore, of Orsett Hall, the owner of the land, who had kindly given permission for our descent, was among those who visited the deneholes on Saturday. This was a very fortunate thing for those interested in the preservation of the deneholes, as he was much impressed by a sight of the damage done by the unauthorised visits of ignorant and destructive boors, and expressed his attention of taking measures to prevent it in future. 